\title{
Aquatic heterotrophic bacteria have highly flexible phosphorus content and biomass stoichiometry
}

\author{
Casey M Godwin and James B Cotner \\ Department of Ecology, Evolution and Behavior, University of Minnesota, 1987 Upper Buford Circle, \\ Saint Paul, MN, USA
}

\begin{abstract}
Bacteria are central to the cycling of carbon $(C)$, nitrogen $(N)$ and phosphorus $(P)$ in every ecosystem, yet our understanding of how tightly these cycles are coupled to bacterial biomass composition is based upon data from only a few species. Bacteria are commonly assumed to have high $\mathrm{P}$ content, low biomass C:P and $\mathrm{N}: \mathrm{P}$ ratios, and inflexible stoichiometry. Here, we show that bacterial assemblages from lakes exhibit unprecedented flexibility in their $P$ content $(3 \%$ to less than $0.01 \%$ of dry mass) and stoichiometry (C:N:P of 28: 7: 1 to more than 8500: 1200: 1). The flexibility in C:P and $\mathrm{N}: \mathrm{P}$ stoichiometry was greater than any species or assemblage, including terrestrial and aquatic autotrophs, and suggests a highly dynamic role for bacteria in coupling multiple element cycles.
\end{abstract}

The ISME Journal (2015) 9, 2324-2327; doi:10.1038/ismej.2015.34; published online 20 March 2015

Terrestrial ecosystems are an important source of nutrients and organic carbon (C) to freshwater rivers and lakes as well as the coastal ocean. Past work has shown that heterotrophic bacteria, a group of organisms that process terrestrial inputs of organic carbon, nitrogen $(\mathrm{N})$ and phosphorus $(\mathrm{P})$ (Biddanda et al., 2001), are C-poor and P-rich (Makino et al., 2003) relative to terrestrial inputs characterized by high C:P ratios. As a result, bacterial assemblages in freshwater ecosystems should experience elemental imbalance and act as efficient exporters of organic carbon to downstream ecosystems. However, freshwater ecosystems metabolize most of the organic $\mathrm{C}$ they receive from terrestrial ecosystems (Cole et al., 2007) and it has been shown recently that strains (Scott et al., 2012) and assemblages (Godwin and Cotner, 2014) of bacteria from lakes can be P-poor and stoichiometrically flexible. Here, we demonstrate that bacterial assemblages from lakes exhibit unprecedented plasticity in their stoichiometry and discuss the implications of flexible composition to ecosystem processes.

To determine the extent of stoichiometric flexibility within assemblages, we performed two experiments in which we cultured the bacteriasized fraction of plankton from a northern temperate lake under varying C:P supply ratios and measured their biomass composition (Supplementary Methods). We created C:P $\mathrm{P}_{\text {supply }}$ ratios from 31.6:1 to more than $220000: 1$ by manipulating the supply of

Correspondence: CM Godwin, Department of Ecology, Evolution and Behavior, University of Minnesota, 1987 Upper Buford Circle, Saint Paul, MN 55108, USA.

E-mail: godwi018@umn.edu

Received 29 September 2014; revised 30 January 2015; accepted 6 February 2015; published online 20 March 2015 phosphate in a defined medium, with all other nutrients in excess of $\mathrm{C}$ and $\mathrm{P}$. At each level of $\mathrm{C}$ : $\mathrm{P}_{\text {supply }}$, we enriched the lake assemblages in batch cultures and used these enrichments to inoculate chemostats at the same C: $\mathrm{P}_{\text {supply }}$. The chemostats were maintained at a dilution rate $\left(0.33 \mathrm{~d}^{-1}\right)$ that is low relative to assemblage growth rates measured in lakes (Cotner et al., 2001).

The bacterial P content decreased from a mean of $3.55 \%$ of dry mass when the assemblage was C-limited to $0.006-0.05 \%$ when the assemblage was most P-limited (Figure 1). The range of $\mathrm{P}$ content measured in the assemblage cultures was nearly equal to the range of existing data in the literature, particularly for P relative to dry mass (Supplementary Table 6). Single-cell measurements from plankton environments indicated the potential for even lower phosphorus quotas (Norland et al., 1995; Cotner et al., 2010), although many of those cells may not be actively growing, potentially decreasing their demand for P-rich RNA, where much of the $\mathrm{P}$ resides in bacterial cells (Makino et al., 2003). The P relative to dry mass values measured here were lower than those reported for a bacterium grown in the absence of added phosphate and high concentrations of arsenate (0.012\% of dry mass as P, Wolfe-Simon et al., 2010). The results presented here clearly demonstrate that bacteria can have P content less than $0.01 \%$ of dry mass when growing at low levels of $\mathrm{P}$.

The C: $\mathrm{P}_{\text {biomass }}$ and $\mathrm{N}: \mathrm{P}_{\text {biomass }}$ of the bacterial assemblages increased from 28:1 and 6:1, respectively, when C-limited to a maximum of $>8500: 1$ and $>$ 1200:1 when P-limited (Figure 1). The ranges of C: $\mathrm{P}_{\text {biomass }}$ and $\mathrm{N}: \mathrm{P}_{\text {biomass }}$ observed in this study cover nearly the entire range of measurements recorded in previous studies for bacterial cultures and assemblages (Figure 2; Supplementary Table 6) and nearly 


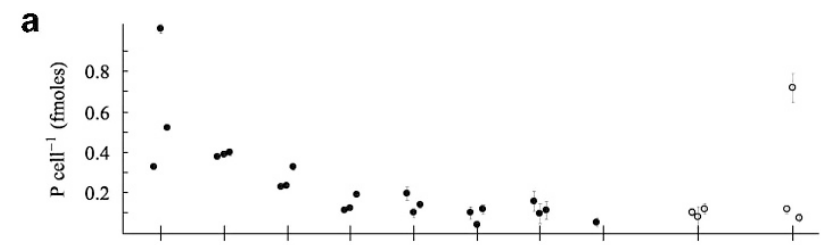

b
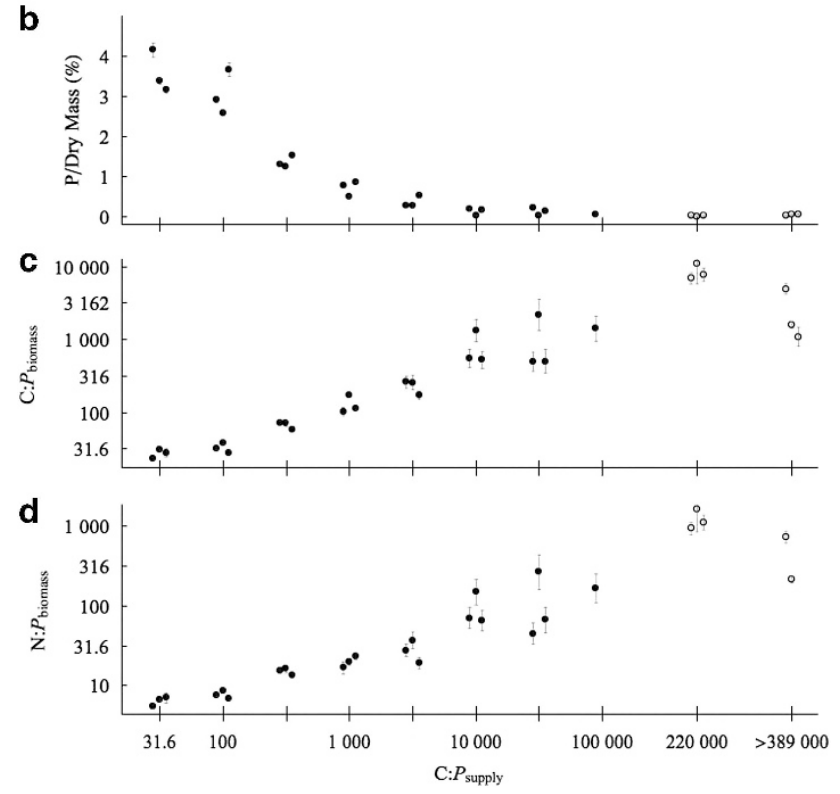

Figure 1 Effect of C: $\mathrm{P}_{\text {supply }}$ ratio on biomass $\mathrm{P} /$ cell (a), $\mathrm{P} /$ dry mass (b), C: $\mathrm{P}_{\text {biomass }}$ (c) and $\mathrm{N}: \mathrm{P}_{\text {biomass }}(\mathbf{d})$ ratios in chemostats diluted at $0.33 \mathrm{~d}^{-1}$. Data from Experiment 1 are displayed as solid circles, and open circles denote data from Experiment 2. At each level of $\mathrm{C}: \mathrm{P}_{\text {supply }}$, the data from replicate chemostat are staggered to improve clarity. The error bars represent the s.e. of the ratio for each chemostat, following propagation of errors from the numerator and denominator. In Experiment 1, C: $\mathrm{P}_{\text {biomass }}$ and $\mathrm{N}: \mathrm{P}_{\text {biomass }}$ (analysis of variance, $P<1 \times 10^{-5}$ ) increased and $P /$ dry mass and $\mathrm{P} /$ cell decreased $(P<0.005)$ significantly with increasing $\mathrm{C}: \mathrm{P}_{\text {supply }}$. On the basis of changes in $\mathrm{C}: \mathrm{P}_{\text {biomass }}$, the assemblage was defined as P-sufficient at $\mathrm{C}: \mathrm{P}_{\text {supply }}$ of $31.6: 1$ and P-limited at $\mathrm{C}: \mathrm{P}_{\text {supply }}$ of 10 000:1 and greater. At C:P $\mathrm{P}_{\text {supply }}$ of $100000: 1$, only one chemostat had $\mathrm{P}$ content above the analytical detection limit and only two chemostats without added $\mathrm{P}$ had $\mathrm{N}$ above the detection limit.

match the ranges of $\mathrm{C}: \mathrm{P}_{\text {biomass }}$ and $\mathrm{N}: \mathrm{P}_{\text {biomass }}$ observed in vascular plant tissues (Elser et al., 2000; Sterner and Elser, 2002; Reich and Oleksyn, 2004). Furthermore, the bacterial assemblage (of multiple strains) exhibited greater stoichiometric plasticity than has been documented in any other species or assemblage, including terrestrial and aquatic primary producers (Sterner and Elser, 2002; Persson et al., 2010). These experiments demonstrate that previous assumptions of low and invariant C:P $\mathrm{P}_{\text {biomass }}$ (Tanaka et al., 2009; Fanin et al., 2013) and high relative $\mathrm{P}$ content for bacteria (Wolfe-Simon et al., 2010) do not represent the physiological flexibility of bacteria in natural assemblages. Although mean cellular $\mathrm{P}$ content decreased under $\mathrm{P}$ limitation, much of the flexibility in $\mathrm{C}: \mathrm{P}_{\text {biomass }}$ was due to a substantial increase in cellular C content (Supplementary Figure 1), likely owing to the accumulation of C-rich storage molecules (Thingstad et al., 2005).

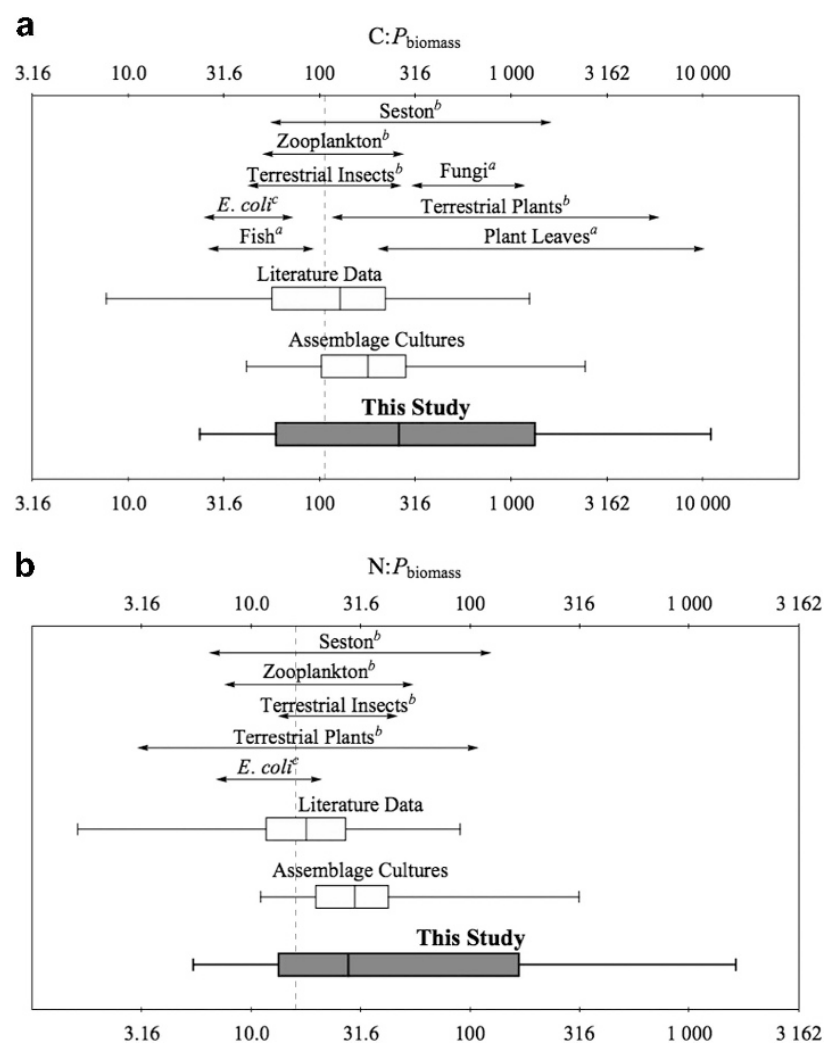

Figure 2 Ranges of C: $\mathrm{P}_{\text {biomass }}$ and $\mathrm{N}: \mathrm{P}_{\text {biomass }}$ for bacterial cultures and other organisms, with separate panels for $\mathrm{C}: \mathrm{P}_{\text {biomass }}$ (panel a) and $\mathrm{N}: \mathrm{P}_{\text {biomass }}$ (panel b). Data for heterotrophic bacteria are separated by sources: literature data (Supplementary Table 7), assemblage chemostat cultures (Godwin and Cotner, 2014) and this study. Ranges for other organisms were from ${ }^{\text {a }}$ (Cross et al., 2005) and ${ }^{\mathrm{b}}$ (Elser et al., 2000). 'Ranges for E. coli were compiled from multiple studies (Supplementary Table 7). Seston refers to suspended particulate matter (phytoplankton, heterotrophs and detritus). The boxplots display data for individual replicate cultures where data are available, with the centerline representing the median, the edges of the box representing the $25 \%$ and $75 \%$ quantiles, and the whiskers representing the maximum and minimum values. Dashed lines indicate the Redfield ratio (C:N: $\mathrm{P}=106: 16: 1)$.

The range of stoichiometric flexibility present in natural assemblages is critical to understanding homeostasis within ecosystems. Strict homeostasis of assemblage $\mathrm{C}: \mathrm{N}: \mathrm{P}_{\text {biomass }}$ leads to the prediction that the ratio of regenerated C:P increases dramatically with increasing resource C:P (Sterner, 1990), but flexible biomass stoichiometry allows tight coupling and negative feedback between bacterial biomass stoichiometry and resource stoichiometry, facilitating the inherent resilience of ecosystems to nutrient perturbations (Scheffer et al., 2001). It is increasingly recognized that much of the organic matter metabolized in rivers and lakes originates in terrestrial ecosystems where C:P and N:P ratios can be much higher than for organic matter originating in aquatic ecosystems (Lennon and Pfaff, 2005). The observations in this study of extreme flexibility in bacterial biomass stoichiometry are consistent with observations of higher and more variable biomass C:P and 
$\mathrm{N}: \mathrm{P}$ in the seston (suspended particulate matter) in freshwaters than in pelagic (offshore) marine systems where terrestrial influences and nutrient gradients are less profound (Cotner et al., 2010).

The bacteria in inland waters and the coastal ocean experience stoichiometric imbalance when they process terrestrial inputs of dissolved and particulate organic matter with high C:P ratios. Compared with bacteria with low and invariant $\mathrm{C}: \mathrm{P}_{\text {biomass }}$, assemblages that increase their $\mathrm{C}: \mathrm{P}_{\text {biomass }}$ in response to this imbalance will remineralize less 'excess' C through respiration and could decrease the export of organic matter to downstream ecosystems. In ecosystems where internal nutrient cycling processes are dominant and bacteria regenerate a large fraction of available nutrients (for example, offshore marine systems), flexible bacterial stoichiometry likely stabilizes dissolved inorganic nutrient concentrations and inhibits fluctuations.

The capacity of heterotrophic bacteria to continue to buffer $\mathrm{C}$ and nutrient feedbacks in ecosystems is likely challenged by the use of inorganic fertilizers that decrease the exported C:N and C:P ratios to aquatic systems (Arbuckle and Downing, 2001) and anthropogenic warming that increases both the export of organic carbon and the C:N:P stoichiometry of that material (Freeman et al., 2001; Urban et al., 2011). Additionally, because stoichiometric flexibility decreases with increasing relative growth rates (Makino and Cotner., 2004; Hillebrand et al., 2013), bacterial assemblages in low-temperature environments could become less flexible as the result of anthropogenic warming. By examining the capacity of aquatic bacterial assemblages to respond to $\mathrm{C}: \mathrm{N}: \mathrm{P}$ imbalance, we can evaluate the influence of stoichiometric flexibility on aquatic ecosystem productivity and the extent and periodicity of nutrient fluctuations.

\section{Conflict of Interest}

The authors declare no conflicts of interest.

\section{Acknowledgements}

Alexandra Daniels helped to run the experiments. This work was funded by NSF IGERT grant DGE-0504195 and NSF-IOS award 1257571 to JC. CG and JC designed the experiments, CG performed the experiments, CG and JC analyzed the results and wrote the manuscript. Jeffery Gralnick, Timothy LaPara, Robert Sterner and three anonymous referees provided comments that improved this manuscript.

\section{References}

Arbuckle KE, Downing JA. (2001). The influence of watershed land use on lake $\mathrm{N}$ : $\mathrm{P}$ in a predominantly agricultural landscape. Limnol Oceanogr 46: 970-975.

Biddanda B, Ogdahl M, Cotner J. (2001). Dominance of bacterial metabolism in oligotrophic relative to eutrophic waters. Limnol Oceanogr 46: 730-739.
Cole JJ, Prairie YT, Caraco NF, McDowell WH, Tranvik LJ, Striegl RG et al. (2007). Plumbing the global carbon cycle: Integrating inland waters into the terrestrial carbon budget. Ecosystems 10: 171-184.

Cotner JB, Ogdahl ML, Biddanda BA. (2001). Doublestranded DNA measurement in lakes with the fluorescent stain PicoGreen and the application to bacterial bioassays. Aquatic Microbial Ecology 25: 65-74.

Cotner JB, Hall EK, Scott JT, Heldal M. (2010). Freshwater bacteria are stoichiometrically flexible with a nutrient composition similar to seston. Front Microbiol 1: 132.

Cross WF, Benstead JP, Frost PC, Thomas SA. (2005). Ecological stoichiometry in freshwater benthic systems: recent progress and perspectives. Freshwater Biology 50: 1895-1912.

Elser JJ, Fagan WF, Denno RF, Dobberfuhl DR, Folarin A, Huberty A et al. (2000). Nutritional constraints in terrestrial and freshwater food webs. Nature 408: 578-580.

Fanin N, Fromin N, Buatois B, Hättenschwiler S. (2013). An experimental test of the hypothesis of nonhomeostatic consumer stoichiometry in a plant littermicrobe system. Ecol Lett 16: 764-772.

Freeman C, Evans C, Monteith D, Reynolds B, Fenner N. (2001). Export of organic carbon from peat soils. Nature 412: 785-785.

Godwin CM, Cotner JB. (2014). Carbon: phosphorus homeostasis of aquatic bacterial assemblages is mediated by shifts in assemblage composition. Aquatic Microbial Ecology 73: 245-258.

Hillebrand H, Steinert G, Boersma M, Malzahn A, Léo Meunier C, Plum C et al. (2013). Goldman revisited: Faster growing phytoplankton has lower N:P and lower stoichiometric flexibility. Limnol Oceanogr 58: 2076-2088.

Lennon JT, Pfaff LE. (2005). Source and supply of terrestrial organic matter affects aquatic microbial metabolism. Aquatic Microbial Ecology 39: 107-119.

Makino W, Cotner JB, Sterner RW, Elser JJ. (2003). Are bacteria more like plants or animals? Growth rate and resource dependence of bacterial C: N: P stoichiometry. Functional Ecology 17: 121-130.

Makino W, Cotner JB. (2004). Elemental stoichiometry of a heterotrophic bacterial community in a freshwater lake: implications for growth- and resource-dependent variations. Aquatic Microbial Ecology 34: 33-41.

Norland S, Fagerbakke KM, Heldal M. (1995). Light element analysis of individual bacteria by X-ray microanalysis. Appl Environ Microbiol 61: 1357-1362.

Persson J, Fink P, Goto A, Hood JM, Jonas J, Kato S. (2010). To be or not to be what you eat: regulation of stoichiometric homeostasis among autotrophs and heterotrophs. Oikos 119: 741-751.

Reich PB, Oleksyn J. (2004). Global patterns of plant leaf N and $\mathrm{P}$ in relation to temperature and latitude. Proc Natl Acad Sci USA 101: 11001-11006.

Scheffer M, Carpenter S, Foley JA, Folke C, Walker B. (2001). Catastrophic shifts in ecosystems. Nature 413: 591-596.

Scott JT, Cotner JB, Lapara TM. (2012). Variable stoichiometry and homeostatic regulation of bacterial biomass elemental composition. Front Microbiol 3: 42.

Sterner RW. (1990). The ratio of nitrogen to phosphorus resupplied by herbivores: zooplankton and the algal competitive arena. American Naturalist 136: 209-229.

Sterner RW, Elser JJ. (2002). Ecological stoichiometry: the biology of elements from molecules to the biosphere. Princeton University Press: Princeton, NJ. 
Tanaka T, Thingstad TF, Gasol JM, Cardelús C, Jezbera J, Sala MM et al. (2009). Determining the availability of phosphate and glucose for bacteria in P-limited mesocosms of NW Mediterranean surface waters. Aquatic Microbial Ecology 56: 81-91.

Thingstad TF, Øvreas L, Egge JK, Løvdal T, Heldal M. (2005). Use of non-limiting substrates to increase size; a generic strategy to simultaneously optimize uptake and minimize predation in pelagic osmotrophs? Ecology Letters 8: 675-682.
Urban NR, Verry ES, Eisenreich S, Grigal DF, Sebestyen SD. (2011). Element cycling in upland peatland wetlands. In: Kolka R, Sebestyen SD, Verry ES, Brooks K (eds), Peatland Biogeochemistry and Watershed Hydrology at the Marcell Experimental Forest. CRC Press: Boca Raton, FL, pp 213-241.

Wolfe-Simon F, Blum JS, Kulp TR, Gordon GW, Hoeft SE, Pett-Ridge J et al. (2010). A bacterium that can grow by using arsenic instead of phosphorus. Science 332: 1163-1166.

Supplementary Information accompanies this paper on The ISME Journal website (http://www.nature.com/ismej) 